\title{
Monomorphic Adenoma: A Diagnosis or a Misnomer? A Review of Literature on Terminologies, Features and Differential Diagnosis of Basal Cell Adenoma
}

\author{
Swati Gupta ${ }^{1}$, Ramakant Gupta ${ }^{2 *}$ and Manju Gupta ${ }^{3}$ \\ ${ }^{1}$ Senior Consultant, Oral and Maxillofacial Pathology, Dr. Jatinder Gupta's Gupta \\ Clinic and Opticals, Haryana, India \\ ${ }^{2}$ Head and Consultant, Department of Dental Services, Dr. Jatinder Gupta's Gupta \\ Clinic and Opticals, Haryana, India \\ ${ }^{3}$ Director and Clinic coordinator, Dr. Jatinder Gupta's Gupta Clinic and Opticals, \\ Haryana, India \\ *Corresponding Author: Ramakant Gupta, Head and Consultant, Department of \\ Dental Services, Dr. Jatinder Gupta's Gupta Clinic and Opticals, Haryana, India.
}

Received: December 01, 2020

Published: December 29, 2020

(C) All rights are reserved by Ramakant

Gupta., et al.

\section{Abstract}

Basal cell adenoma, previously was termed by few authors as Monomorphic adenoma. The term "Monomorphic adenoma" was originally proposed for any benign epithelial salivary gland tumour other than benign mixed tumors. Monomorphic adenoma included tumours such as Warthins tumour, basal cell adenoma and canalicular adenoma. However, in the new 2005 WHO classification of salivary gland tumours the term "monomorphic adenoma" is not included and basal cell adenoma is considered as a separate entity. This paper intends to discuss the controversies regarding the terminology and classification of monomorphic adenoma along with diagnosis and differentiation of basal cell adenoma from other tumours.

Keywords: Adenoid Cystic Carcinoma; Basal Cell Adenoma; Basal Cell Carcinoma; Canalicular Adenoma; Epithelial Salivary Gland Tumour; Monomorphic Adenoma; WHO Classification

\section{Abbreviations}

ACC: Adenoid Cystic Carcinoma; BCA: Basal Cell Adenoma; BCC: Basal Cell Carcinoma; CA: Canalicular Adenoma.

\section{Introduction}

Basal cell adenoma (BCA) is uncommon benign epithelial salivary gland neoplasm, with a uniform histologic appearance dominated by basaloid cells $[1,2]$. BCAs constitute approximately 1-2\% of all salivary gland epithelial tumors and majority of cases arise in parotid gland of elderly patients [1-5].

BCA was first described and adequately documented a distinct entity by Kleinsasser and Klein in 1967 [3,6]. It was classified as a subtype of monomorphic adenomas by WHO in 1972 [7]. But, few authors termed BCA itself as monomorphic adenoma leading to controversies. The term "monomorphic adenoma" was originally proposed for any benign epithelial salivary gland tumour other than benign mixed tumours by Rouch in 1970 [7].

In 1991 and 2005, BCAs are classified by WHO as one of the nine subcategories of salivary gland epithelial tumours, and the term monomorphic adenoma was not included in the classification due to controversies associated with the term [8,9]. The same have been continued to follow in WHO 2017 classification of benign salivary gland tumors [10].

However, few investigators are still using the term, adding on to the confusion [11,12]. Therefore, this paper intends to discuss the controversies regarding the terminology, along with features and differential diagnosis of basal cell adenoma from other tumours. 
Monomorphic Adenoma: A Diagnosis or a Misnomer? A Review of Literature on Terminologies, Features and Differential Diagnosis of Basal Cell Adenoma

\section{Materials and Methods}

For this review, articles in English language were identified by searches on electronic data bases such as Google, Google scholar, Ebscohost, and Pubmed from 1960 through July 2020. The follow-ing search terms were used: "Monomorphic adenoma", "Basal cell adenoma", "basal cell adenoma and diagnosis", "differential diag-nosis monomorphic adenoma", "basal cell adenoma and clinical features", "histopathology basal cell adenoma", "monomorphic ad-enoma and related terminologies", "basal cell adenoma and related terminologies".

\section{Results and Discussion}

Salivary gland neoplasms are uncommon, comprising less than $3 \%$ of all head and neck tumors [13]. Approximately $88 \%$ of salivary gland neoplasms are epithelial in origin and basal cell adeno$\mathrm{ma}$, the most common variant in group of monomorphic adenomas, accounts for only $1-2 \%$ of all salivary gland epithelial neoplasms [14]. More than $80 \%$ of BCA arise in parotid gland and their occurrence in minor salivary gland is relatively rare, involving minor salivary glands of upper lip [14]. Other rare sites may include buccal mucosa, palate and lower lip [14].

The tumor may occur in any age, but is most common in middle aged and older adults with average age of 57.7 years, although, few cases of BCA in $4^{\text {th }}$ decade of life has been reported [14]. The literature is controversial about sex predominance. Male predominance has been reported by few authors, while few have reported female predominance [14].

BCA for the first time was described and adequately documented as a distinct clinical and pathological entity by Kleinsasser and Klein in 1967 [7]. But, the Confusion and disagreement regarding name existed since its designation. Other terms used for BCA included Tubular adenoma, Trabecular adenoma, Dermal analogue tumor, Canalicular adenoma, Basaloid adenoma, Clear cell adenoma and Monomorphic adenoma [7].

WHO in 1972, classified BCA under category of monomorphic adenoma. Batsakis and Branon in 1981 gave histological classification of monomorphic adenoma (Table 1) [15]. In 1983, Gardner and Daley were first authors who made distinction between BCA and canalicular adenoma [16]. WHO in 1991 did not included the term monomorphic adenoma in its new classification of salivary gland tumors due to controversies associated with the term and
BCA was considered as a separate entity [8]. Currently, BCA is considered as one of the nine subcategories of salivary gland epithelial tumours according to WHO 2005 and 2017 classification of salivary gland tumors $[9,10]$. And also, basal cell adenocarcinoma, the malignant counterpart of BCA has been introduced as a separate entity under malignant tumors $[9,10]$.

\begin{tabular}{|c|c|c|}
\hline S. No & Category of tumour & Tumour \\
\hline 1. & $\begin{array}{c}\text { Tumours of terminal } \\
\text { duct origin }\end{array}$ & $\begin{array}{l}\text { A. Basal cell adenoma } \\
\text { B. Canalicular adenoma }\end{array}$ \\
\hline 2. & $\begin{array}{c}\text { Tumours of terminal } \\
\text { or striated duct } \\
\text { origin }\end{array}$ & $\begin{array}{l}\text { A. Sebaceous adenoma } \\
\text { B. Sebaceous lymph adenoma }\end{array}$ \\
\hline 3. & $\begin{array}{l}\text { Tumours of striated } \\
\text { duct origin }\end{array}$ & $\begin{array}{l}\text { A. Oncocytoma } \\
\text { B. Papillary cyst adenoma lym- } \\
\text { phomatosum }\end{array}$ \\
\hline 4. & $\begin{array}{l}\text { Tumours of excre- } \\
\text { tory duct origin }\end{array}$ & $\begin{array}{l}\text { Sialadenoma papilliferum or } \\
\text { inverted ductal papilloma }\end{array}$ \\
\hline
\end{tabular}

Table 1: Histological Classification of Monomorphic Adenoma by Batsakis and Branon in 1981 [15].

Basal cell adenoma, as defined by WHO, is a distinctive benign neoplasm, composed of basaloid cells organized with a prominent basal cell layer and distinct basement membrane-like structure and no myxochondroid stromal component as seen in pleomorphic adenomas [17]. Clinically, BCA occur as slowly growing, asymptomatic, firm swelling. In general, BCAs are considered to be small tumors with less than 3 centimetres of greatest diameter $[3,18]$. Grossly, they have been described as round to oval well circumscribed with a smooth surfaced capsule and with a soft to moderately firm consistency $[3,18]$.

The origin of basal cell adenoma is epithelial, and is thought to originate from cells of intercalated ducts [3]. But, it has also been described as benign homologue of adenoid cystic carcinoma (ACC) as hybrid tumors composed of ACC and BCA has been reported in literature [3]. They exhibited intermingled patterns indicating transition from one type of tumor to other or common origin of both $[3,19]$.

Histologically, BCAs have various variants, including solid, trabecular, tubular and membranous variants. The most common type is solid variant, but individual tumors displaying combination of several growth patterns $[3,19]$. BCAs are composed of basa- 
Monomorphic Adenoma: A Diagnosis or a Misnomer? A Review of Literature on Terminologies, Features and Differential Diagnosis of Basal Cell Adenoma

loid cells having two morphologic forms that are intermixed. One is small cells with scant cytoplasm and a round deeply basophilic nucleus. The other is a larger cell with amphophilic to eosinophillic cytoplasm and a nucleus that is more ovoid and pale staining than that of smaller cells $[3,19]$. The larger cells generally predominate with smaller darker cells located in peripheral portions of tumor nests, cords or islands $[3,19]$. The inner cells of tumor mass may produce scattered whorled eddies, on occasions these eddies may mature into sebaceous cells and produce keratin to give appearance of keratin pearls $[3,19]$. The trabecular subtype has similar features as that of solid form but, epithelial islands are narrower and cord like. The tubular patterns exhibit multiple small round duct like structures $[3,19]$. Both trabecular and tubular patterns may be seen in conjunction to form compound trabeculo- tubular pattern. The membranous BCA is also similar to solid variant but, is usually multilobular and the epithelial islands are arranged in large lobules $[3,19]$. The distinctive feature of membranous BCA is the thick PAS positive eosinophillic hyaline layer that surrounds the epithelial islands and separates them from one another $[3,19]$.

Clinical differential diagnosis include mucocele, irritational fibroma, or other minor salivary gland tumors [1-4]. Mucocele is typically a dome shaped mucosal swelling that can range from $1 \mathrm{~mm}$ to several centimetres. The mucosa usually imparts bluish translucent hue due to spilled mucin [1-4]. Characteristically, fluctuant but may be firm on long standing. Although it more commonly affects young individuals but, may occur in elder patients [1-4]. Lower lip is most common site but may occur on palate, cheek, tongue, floor of mouth and no case in literature has been reported on upper lip [1-4]. Irritational fibroma is the most common benign soft tissue neoplasm occurring in oral cavity due to trauma or local irritation [1-4]. Although it frequently occurs on gingiva but may occur at any site including buccal mucosa, tongue, lips and palate [1-4]. It usually presents as small, slowly growing, well defined, sessile/pedunculated elevated nodule of normal color with smooth surface [1-4].

Histopathological differential diagnosis includes cellular variants of pleomorphic adenoma, CA, ACC and BCC [20]. Pleomrphic adenoma is most common benign tumor of salivary glands. Its cellular variant with almost complete absence of the characteristic myxochondroid structure may be difficult to differentiate it from BCA. But, the absence of spindle or plasmacytoid differentiation of epithelial cells helps to differentiate BCA from pleomorphic adenoma. CA occurs in patients over age of 50 years with peak inci- dence of 7 th decade. The tumor commonly occurs in females and common site of occurrence is upper lip. Histologically, CA is well circumscribed with variable encapsulation. The epithelial component comprise of bilayered strands of columnar cells arranged in canaliculi. There may be focal collection of basaloid cells and appearance may be similar to BCA. The distinguishing feature of CA is characteristically loose and paucicellular stroma with prominent vascular pattern. Absence of same in BCA helps it to distinguish from CA. Among malignant tumor, the ACC and basal cell adenocarcinoma are the lesions which shows histologic similarities to BCA. However, characteristics such as integrity of basal layer, decreased number of mitoses, slow growth and absence of perineural invasion are typical of benign lesions.

Immunohistochemically, basaloid cells express vimentin, actin, ß- subunit of S- 100 and cytokeratin [19,21]. Pan cytokeratin, S- 100 and smooth muscle actin (SMA) in the tumor indicate the participation of myoepithelial cells also in histogenesis [19,21].

Conservative surgical excision is essentially the treatment of choice for all monomorphic adenomas. But, occasional reoccurrence has been reported in oncocytoma and few reports reported high recurrence rate (24\%) of the membranous type BCA [1-3]. Malignant transformation of membranous type BCA and Hybrid tumours consisting of basal cell adenoma and adenoid cystic carcinoma have also been reported. Therefore it is necessary to distinguish BCA from other tumors [22].

\section{Conclusion}

Due to prognostic implications related to BCA it is important to diagnose it as separate entity. And it is more apt to use the term "Basal cell adenoma" as the diagnosis which is precise entity rather than using the term momomorphic adenoma, which constitutes a group of benign epithelial salivary gland tumors.

\section{Acknowledgements}

The authors acknowledge divine presence of Late Dr. Jatinder Kumar Gupta and dedicate whole work to him. The authors also ac-knowledge the writing assistance by Angel Medical Solutions (E-mail-: angelmedicalsolutions@gmail.com). This research received no specific grant from any funding agency in the public, commercial, or not-for-profit sectors.

\section{Conflict of Interest}

The authors declare that there is no conflict of interest. 


\section{Bibliography}

1. Gupta S., et al. "An unusual case report of basal cell adenoma: A Diagnostic Enchanter". Journal of Clinical and Experimental Dentistry 65 (2014): e599-601.

2. Minicucci Eliana Maria., et al. "Basal cell adenoma of the upper lip from minor salivary gland origin”. European Journal of Dentistry 2 (2008): 213.

3. Gupta N., et al. "Basal cell adenoma in a relatively rare site". Journal of Oral and Maxillofacial Pathology: JOMFP 13.2 (2009): 101.

4. Jang M., et al. "Basal Cell Adenoma in the Parotid Gland: CT and MR Findings". American Journal of Neuroradiology 25 (2004): 631-635.

5. Crumpler C., et al. "Monomorphic adenomas of salivary glands. Trabecular-tubular, canalicular, and basaloid variants". Cancer 38 (1976): 193-200.

6. Mărgăritescu C., et al. "Salivary gland Basal cell adenomas--immunohistochemical evaluation of four cases and review of the literature". Romanian Journal of Morphology and Embryology 46.1 (2005): 29-40.

7. Gardner David G and Tom D Daley. "The use of the termsmonomorphic adenoma, basal cell adenoma, andcanalicular adenoma as applied to salivary gland tumors". Oral Surgery, Oral Medicine, Oral Pathology 56.6 (1983): 608-615.

8. Seifert Gerhard and Leslie H Sobin. "The world health organization's histological classification of salivary gland tumors. A commentary on the second edition". Cancer 70.2 (1992): 379-385.

9. Eveson JW., et al. "Tumours of the salivary gland". In: Barnes L, Eveson JW, Reichart P, Sidransky D, editors. World Health Organization classification of tumours: pathology and genetics of head and neck tumours. Lyon: IARC (2005): 164.

10. Slootweg P J and Adel K El-Naggar. "World Health Organization 4th edition of head and neck tumor classification: insight into the consequential modifications". Virchows Archiv 472.3 (2018): 311-313.

11. Sharma BB., et al. "Buccal Monomorphic Adenoma: a case report". European Journal of Medical Case Reports 1.1 (2017): 51-55.

12. Spector Matthew E. "Multiple Parotid Masses: A Rare Case of De Novo Monomorphic and Pleomorphic Adenomas in a Patient with Myotonic Dystrophy". Journal of Case Reports in Medicine 6.1 (2017).

13. Bell Diana and Ehab Y Hanna. "Salivary gland cancers: biology and molecular targets for therapy". Current Oncology Reports 14.2 (2012): 166-174.
14. Chiu Nai-Chi., et al. "Basal cell adenoma versus pleomorphic adenoma of the parotid gland: CT findings". American Journal of Roentgenology 189.5 (2007): W254-W261.

15. Batsakis J G., et al. "Monomorphic adenomas of major salivary glands: a histologic study of 96 tumours". Clinical Otolaryngology and Allied Sciences 6.2 (1981): 129-143.

16. Bhagde Priya Anil., et al. "Basal cell adenoma of maxillary sinus mimicking ameloblastoma”. Journal of Oral and Maxillofacial Pathology: JOMFP 20.1 (2016): 142-146.

17. Veeresh M., et al. "Basal cell adenoma of the submandibular gland". Journal of Maxillofacial and Oral Surgery 9.3 (2010): 289-291.

18. Yadav Achla Bharti., et al. "Basal cell adenoma of palate, a rare occurrence with review of literature". Journal of Dentistry 16.3 (2015): 291.

19. Dardick I., et al. "Salivary gland monomorphic adenoma. Ultrastructural, immunoperoxidase, and histogenetic aspects". The American Journal of Pathology 115.3 (1984): 334-348.

20. Paker Irem., et al. "Basal cell adenoma with extensive squamous metaplasia and cellular atypia: a case report with cytohistopathological correlation and review of the literature". Diagnostic Cytopathology 40.1 (2012): 48-55.

21. Zarbo Richard J., et al. "Salivary gland basal cell and canalicular adenomas: immunohistochemical demonstration of myoepithelial cell participation and morphogenetic considerations". Archives of Pathology and Laboratory Medicine 124.3 (2000): 401-405.

22. Jeddy Nadeem., et al. "Membranous Basal Cell Adenoma - A Rare Entity in an Unusual Location". Journal of Clinical and Diagnostic Research : JCDR 11.4 (2017): ZD21-ZD22.

\section{Assets from publication with us}

- Prompt Acknowledgement after receiving the article

- Thorough Double blinded peer review

- Rapid Publication

- Issue of Publication Certificate

- High visibility of your Published work

Website: www.actascientific.com/

Submit Article: www.actascientific.com/submission.php Email us: editor@actascientific.com

Contact us: +919182824667 